\title{
Elasticity of Credit Demand in Agriculture Sector in Pakistan
}

\author{
M. Taimoor Hassan \\ Lecturer, Department of Management Sciences, The Islamia University of Bahawalpur, \\ Pakistan \\ E-mail: taimoor.abbasi@iub.edu.pk
}

\begin{abstract}
Atif Rehman, Attia Rizvi, Rubab Khan, Sunia Ayuub, Uzma Baloch and Bilal Sardar
Department of Management Sciences, The Islamia University Bahawalpur, Pakistan
\end{abstract}

\author{
Muhammad Arfan Lodhi \\ Training Advisor, Human Resource Management Academic Research Society \\ $\mathrm{PhD}$ Scholar \& Visiting Lecturer, The Islamia University of Bahawalpur, Pakistan \\ E-mail: Samaritan_as@hotmail.com
}

Accepted: January 17, 2012 Published: March 17, 2012

Doi:10.5296/ijld.v2i1.1523ＵRL: http://dx.doi.org/10.5296/ijld.v2i1.1523

\begin{abstract}
Purpose: The purpose of this paper is to investigate fundamental factors that bring change in the demand of credit in agriculture sector of Pakistan. Furthermore it measures the effect of these factors on agriculture credit requirement.

Design/methodology/approach: Field research was conducted. The questionnaire was formed by an amalgamation of existing relevant literature. The main research target sample consisted of residential farmers in Pakistan. Reliability tests and statistical analyses were executed to verify both scale validity and reliability and answer the research questions.

Findings: Factors driven from the elasticity of credit demand in agriculture sector are climate change, interest rate, investment in micro irrigation system, and credit worthiness have shown least variation in the statistical results which shows that these variables have immense effect on the demand of credit in Agriculture sector.

Research limitations/implications Results may not generalize outside Pakistan or to other financial services.

Practical implications: The present study helps the Government and financial institutes to understand and find solution of those factors which cause decrease in agriculture credit demand. The study can also help in making policy which is related to financial matter in agriculture sector.
\end{abstract}


Originality/value: _ This paper mainly reveals the consequence of financial and economical factors on elasticity of agriculture credit demand.

Keywords: Credit Demand, Agriculture Credit, Elasticity

\section{Introduction:}

The research in conducted for determining those factors which directly or indirectly affect the elasticity of credit demand in agriculture sector. As Pakistan is considered an agriculture country, peasants need capital for enhancing and bringing growth in the agriculture sector. For this need most of the peasant demand loan from financial institutes. In this study policies of financial institutes and government, need of agriculture inputs, climate conditions are highly responsible for increase or decrease in demand for rural credit. Interest rate has power full effect on investment and agriculture credit so we can relate investment with cost of capital. High interest rate encourages external financing (Fry, 1995). Policies of financial institutes about interest rate and credit lending procedures are highly important. It was found that level of education is an important aspect of credit demand. As low level of education, decreases the chances of credit access and vice versa (Mohamed, 2003). Agriculture is highly elastic to climatic change and weather extremes. The forces that bring changes are also very important for productivity. Due to the uncertainty of heat stress, floods and rainfall or crop disease have negative effect on agriculture products (IPCC, 2007).

\section{Theoretical background:}

\subsection{Interest:}

Rent for the use of credit, paid by borrower is called interest rate. Interest rate also performs intellectual function of allocating limited supply of credit among different competing demand (Ibimodo, 2005). According to Ani (1988) high investment rate effect the lending capacity of banks which effects money circulation and investment. Nwanko (1989) said that banks will more efficienctly allocate loans because high rate of interest shows shortness of money resources. So it will become difficult for agriculture farmers to access these loans due to limited credit capacity of granting loans. Due to high interest rate and the default in repayment of loan, Government can stop disbursement of loans (Agbelie, 2001). Saving and investment theory of Keynesiar and by Machinnon (1973; cited in Adofu, Abula, \& Audu, 2010) and Shaw (1973) considers saving an important tool to increase investment demand when interest rate is high. Due to high interest rate people mostly prefer to save, so banks can lend more money when it has more amount of saving. Due to these investments and saving relationship, productive investment increases. Keynes said quantity of money saving or supply is very important because when supply of money is equal to the demand then there will be equilibrium in interest rate. In other words we can say that supply and demand for money both affect interest rate. Supply (saving) and demand (investment or marginal efficiency of capital) used to maintain interest rate. Due to increase in saving, interest rate and cost of capital will reduce. Production pattern changes from low investment to high investment approach, as the result demand for credit increases but this approach is against capital theory (Hardwick, Khen and 
Langmead, 1990). High credit risk or default repayment is more concerned to bank, so they use more effective ways to distribute loans among farmers (Anderson, 1990). High rate of interest affects the loan advancement and that will affect loan repayment (Stiglitz and Weiss, 1981). According to Besley and Coate (1995) repayment of loan is not $100 \%$ at any positive interest rate. So increase in interest rate will increase production cost. However if profit will decrease in any activity for which loan has taken, the loan default will increase.

\subsection{Climate change:}

Climate means general picture of all weather condition for a long time period (Anwar, 1993). It means that change in climate is due to the nature or degradation of environment activities, and change is for long time. Agriculture is highly elastic to climate change and weather extremes. The forces that bring changes are also very important for productivity. Due to the uncertainty of heat stress floods and rainfall or crop disease have negative effect on agriculture products accurately they have surprising nature. When there is lengthy duration of growing seasons extreme weather, crops are affected by summer heat due to reduction in soil dampness. They will affect the agriculture products and demand for agriculture credit increases. Increase in temperature is due to the increase in $\mathrm{CO}_{2}$ level. But some crops get benefits from this heat (IPCC, 2007). In Punjab, Sindh and Balochistan temperature has slow increase over last seventeen years. But there is slight decrease in temperature in K.P.K. One degree increase reduces food product by forty four kilo per hectare (Ahmad and Schmitz, 2011). Due to the overall temperature increase, glaciers are melting, which increase the supply of water. When the water is available then land area of agriculture is increased, so the level of agriculture production and requirement of loan increased (Janjua, Samad, \& Khan, 2009). Soil cutting and soil dampness depends on rain fall and both are very important for crops (IPCC, 2007). Agriculture production is mainly influenced by weather and climate conditions. In 1987 short monsoon rains effected crop production in Bangladesh, India and Pakistan, which in return affected their import pattern (World food institute, 1998). Pattern of rain is changing due to change in climate. More rains have positive effect on the production (Janjua, Samad, \& Khan, 2009). Extreme natural threats (wind storms and floods) and human influenced threats (terrorist attacks) are threats for the society and changing environment (Bosher et. al, 2009). Natural and human disaster and threats have little effect on economy. But the size and quantity of these extreme disaster is increasing due to the change in climate, so the environment become more uncertain (Cabinet office/ HM treasury, 2006). Flood processes are started due to the change in climate or non climatic process. Future climate is not predictable because of uncertainty of heat waves floods, crop disease, and surprising climate change. We can measure or predict these changes up to some extent but we cannot exactly tell about the effect of these factors (IPCC, 2007).

\subsection{Information Gap between lenders and borrowers:}

The major reason of information gap between lenders and borrowers is that in rural areas people rely to borrow money from Village money lender or informal lender. That's due to quick approach; inflexible terms and informal way (Ekumah \& Essel, 2003). In Uganda 79\% of rural people obtain loans from non formal financial institutions including village money 
lenders, relatives and local credit providers. Because during 1970's and 1980's rules of fixed rate of interests were applied and most of the banks were controlled directly by African government. There are also other factors like income of borrower, non-availability of financial institute in specific geographic area, demand of security for loans, flexibility in terms and need of least amount of balance (Mpuga, 2004). Informal financial institutions always work in rural areas but they are not dependent on policies of government. Informal institutions are not concerned with agricultural development as well as they apply high rate of tax so that borrower becomes unable to repay loan (Lai \& Cistulli, 2005). Physical existence of bank and direct contact with bank brings information about rules towards customers. As bank's outreach programs and advertisement through billboards failed to create awareness about credit terms (Ekumah \& Essel, 2003). The demand of credit in formal sector can be increased and in informal sector can be decreased if debtors easily approach the funds from govt. institutions. Moreover, the requirements of debtor can also be fulfilled by these funds (Hoff \& Stiglitz, 1993).The result of study shows that as the distance increases the credit demand gets decrease (Mpuga, 2004). Mostly in eastern Asian states, lack of transparency is responsible for crisis in financial institutes. Lack of transparency is due to interfering of politicians and mismanagement. As latest forms of information are not present, the bank focuses on private contacts in process of selecting debtors (Ekumah \& Essel, 2003). The study has shown that available information is intelligible for customers just because of lack of transparency and low level of education (Hoff \& Stiglitz, 1993). To deliver information Front desk officers and managers play vital role for the customers. Most of the customers avail information about credits through clerks or managers while small number of customers is aided by accountants. Most of the customers don't know how to take opportunity of loans (Ekumah \& Essel, 2003). The terms and conditions and their related compulsions regarding rural credits can't reach to small farmers, as mostly small farmers are illiterate (Ekumah \& Essel, 2003). The study has proved that customer faces difficulty to understand the information about credit due to two reasons, one is lack of transparency and other one is low level of education of borrowers (Hoff \& Stiglitz, 1993).

\subsection{Economic Conditions}

Now the credit is extensively used as an alternative of money. At the time of inflation tax rate is more on money so people prefer credit as inflation is increasing day by day. The inflation has increased the number of those buyers who want to take credit on low interest rate and decreased the number of those who take credit on high interest rate. As, when the level of inflation is low, the obtained credit has no successful benefits for the society but when the inflation increase to a certain level the increase in credit demand has been proven beneficial for the society (Dong, 2008). Inflation and credit has negative relationship that means inflation creates negative effect on credit, but only when the inflation increases to the limit (Boyd et al, 2001). As the repayment of the loan is in the form of money so rate of interest is increased with the high inflation rate (Duca \& Whitesell, 1995). To approach the outside resources in agriculture there are some forces which create problems e.g. the function of credit in the system of economy, the day by day increasing inflation, ambiguity, danger to invest or the decreasing profit ratio in agriculture cause damage in the production, so government provide subsidies to solve these 
problems like providing financial assistance, security credit funds. The result is more demand for the credit (Swinnen , 1994). Because of the flawed or the defective information in market of economy the credit demand will be affected in agriculture (Stiglitz, 1993). The one who receives loans have certain conditions for the repayment of loans. The increasing interest rate means the increasing repayment so farmer or the borrower also thinks about the chance of risk in profitability so the expectation of the farmer for the profit will be decreased. Consequently the credit demand decreases but if the bank has limited the amount of loan given and also fixed the interest rate on it, then credit demand will be increased (Stiglitz and Weiss, 1981; De Meza and Webb, 1992).

\subsection{Credit Worthiness:}

Agricultural borrowers are now having concerns about how they can access the credit. Many credit standards have tightened the commercial banks along with financial crisis and economic weaknesses. The credit borrowers have interest in availability of credit and the same time the credit lender concerned about the creditworthiness of agricultural borrowers (Henderson, 2009).The primary the most important factor which the financial institute have to check while lending the agricultural loan are first while analyzing the agricultural loan application determine the importance of financial and nonfinancial information, second identify the characteristic of lender and borrower which is important in suggesting interest rate and approval of loan. Agricultural lenders use the five C's of credit (capacity, capital, collateral, character and condition) when evaluating the agricultural application of loan. The community and the borrower judge that whether the borrower has an ability to repay the loan (Gustafson, 1989). There are three main factors that are necessary for the repayment of credit are first is financial capability means the borrower must have the capacity to repay the loan. It the farmers have the weak financial capability they have little chance to repay the credit. So it's a key factor for extending the loan to the farmers. The second factor is the character of borrower it may possible that the borrower has the capacity to repay the loan but he has somewhat unreliable character regarding repaying the credit. So the person who has assured the guarantee of the borrower has the responsibility to recall him about credit, and also make him ashamed to repay the credit to the credit officers. But some of the farmers who had made the repayment of credit on time, their character was more sound than financial capability (Sjah et al, 2003). The third most important factor is that the motivation of the farmers toward to credit because he made the payment of debt before time because he wants to get the credit again in future. The credit officers should be frequently visited to the borrower and also they should motivate to repay the loan. The another method is to make the payment as soon as possible and get rid of all the worries as like the accumulated interest and pressure of having debt (Anderson \& Hamal, 1983).

\subsection{Investment in Micro Irrigation System}

The organization can provided the better services if they use the external sources and make partnership with different companies for more availability of cash products, keep the cost low, and also adopting the proper rules and regulation such as SACCOs and MBOs (Nagarajan \& 
Meyer, 2005). The rural finance and finance products can be made easily available by reduction of cost of provision of loan, and also ensuring the high recovery of loan. All this is possible by whole saling and retailing partnership as like between agriculture banks, farmer cooperatives, commodity association and MFIs (Nagarajan \& Meyer, 2005). The most common challenge in many countries is not proper legal framework. It may regulate the microfinance availability but not smooth innovation. The sustainability of MFI is required the proper utilization of savings (Zeller \& Meyer, 2002). The provision of micro finance for irrigation system is limited because in some countries the NGOs are not allowed to collect the deposit from public (Murdoch, 2000). For the purpose to save the savings of the poor from fraud and unreliable sources some countries are made the special licensed for regulation and control the microfinance institutes (Nagarajan \& Meyer, 2005). To make the financial system more inclusive financial system the main thing is financial transparency. The financial transparency means the availability of relevant, accurate, timely, and comparable information about the performance of financial institution (Helms, 2006). For the purpose to provide the rapid financial services to the poor farmers the managers need the proper information that helps them to make better decisions to improve the repute of their institutes and helps to private and public donors to provide their funding to these institutes (Helms, 2006). The financial transparency is also important for the clients because it creates the competition among the institutes and the financial products are available at very low interest rates (Helms, 2006). The two traditional instruments commonly reduce the interest rates one is pricing policy and other is development of competition in this sector (Hudon, 2007).

\subsection{Agricultural input:}

Change in technology, use of agricultural input and technical efficiency is the three important factors helpful in agricultural growth. Technological changes come from more development efforts whereas the adoption of new technology is effected by the better infrastructure, managerial capacity of farmer, funds availability and the flow of information. High and better use of input mix also required funds. This came from the own saving of farmer and also from borrowing. In under developed countries like Pakistan, where the saving of farmer is so small for high productivity the new technology and the agricultural credit are considered as a necessary input. Due to increase in use of biocides, fertilizers, mechanization and improved seeds the requirement of credit increases in farming sector. In Pakistan the credit system is consisted of two sources formal and informal source of credit. Friends, relatives, traders, commission agent and private money lenders are the informal resources whereas formal sources are the financial institutes like Zarai Taraqiati Bank Limited (ZTBL), Agricultural Development Bank of Pakistan (ADBP), commercial Banks and Federal Bank for Cooperatives, now a day some non government organizations (NGOs) are also giving the credit in agricultural sector. Like most developing countries subsidized institutional credit is now widely used in Pakistan (Iqbal, Ahmad, \& Abbas, 2003). Increase in subsidized institutional credit is exercise in mostly developing countries like Pakistan. The purpose is to get the higher productivity by using the new coming technology and relaxing liquidity leading for the greater usage of inputs. In Pakistan there are only few studies relating to the effect of institutional credit in agriculture sector. Zuberi (1989) estimated the production purpose in agriculture sector and find that the impact arises through financing of fertilizers and seeds on 
institutional credit. Agricultural output also affects the Institutional credit by the financing of capital investments. The reaction of output fertilizers on institutional credit is less than the agriculture output (Qureshi and Shah, 1992). In 1972 reforms the commercial banks need to wide there scope of lending credit for the use of investments and modern farm inputs. The banks have to fulfill the target for agricultural sector and they are subject to the penalties if they do not meet the required target. Not just like the other formal institutes the commercial banks fully depend for the financing in agricultural credit on their deposits. Estimate of agriculture credit is also prepared by Pakistan.

\subsection{Government Policies and Rules \& Regulation:}

The government plays an important role in the microfinance provision industry. The government provides the accumulated grants to the financial institutes as like NGOs and MFIs. The government also facilitates to provide loan to the poor in the shape of self help groups (SHGs.). For the purpose to eliminate the unfair competition from microfinance sector the government should make stronger market system by providing the budgetary disclosure and annual report for all the government microfinance activities and also ensure that the lender is providing loan only at commercial rates. The regulatory reform will be maintaining the actual integrity of financial system. The rules and regulations also help to increase the supply of microfinance into the financial market. The main key point is to authorize to non depository MFIs to extend credit only without any special supervision and eliminate all financial oppressive prudential regulations. The Government should apply the special standards to reflect the specialized nature of micro finance, revise all banks branching rules and regulations, regularize taxation rates and permit foreign equity participation in microfinance (Hubka \& Zaidi, 2005). The situation is that microfinance industry has followed the improper pattern to implement the rules and regulation. The financial institutes depend on the money of other people's as like donor supported NGOs are legally authorized but not proper regulation and supervision. The financial institutes members' money usually supervise by the non financial cooperative authority and the institutes used the public's money as like banks but not proper regulation and supervision (van Greuning, Gallardo \& Randhawa, 1998). The regulation should be that high interest rate will be borne by the politicians and the regulators will understand the risk of credit whether they have ability to repay loan or not. It would begin to determine the factors that are explained by banks while entering into the micro finance sector (World Bank, 2003). For the purpose to implement the regulatory reform in the microfinance sector should follow the basic of prudential regulation. The regulation and rules should be controlled by the deposit-taking institutes but the non deposit-taking institutes should left the market for discipline. In other words, say that the liability side of balance sheet will be made the rules and regulation (Meagher, 2002).In addition to the regulatory reform the government can take action to improve the business environment in financial sector due to attention toward microeconomic stability, strong the banking mechanism, improve infrastructure especially into the rural areas (Hubka \& Zaidi, 2005). The traditional banking system should take step for the development of microfinance services. There may be a bank that is not dealing with microfinance services but the basic banking system can also provide the sound base for consistent microfinance environment. The NGOs and MFIs will require the banking services 


\section{Macrothink $\Lambda$ Institute ${ }^{m k}$}

for deposit funds without this they cannot excess the external funding for the operations (Fernando, 2003). The basic infrastructure in rural areas is providing tool for availability of microfinance as well as the productive use of financial resources by the borrower. The availability of health and education facilities will help to improve the economic conditions of the poor (Fernando, 2003). For the purpose to create the discipline into commercialized market makes the rating of MFIs (micro finance institutes). The logic behind the rating of MFIs has come to know about the subsidy dependence banks or financial institutes that is state-owned (Yaron, 2003).

\section{THEORETICAL FRAMEWORK:}

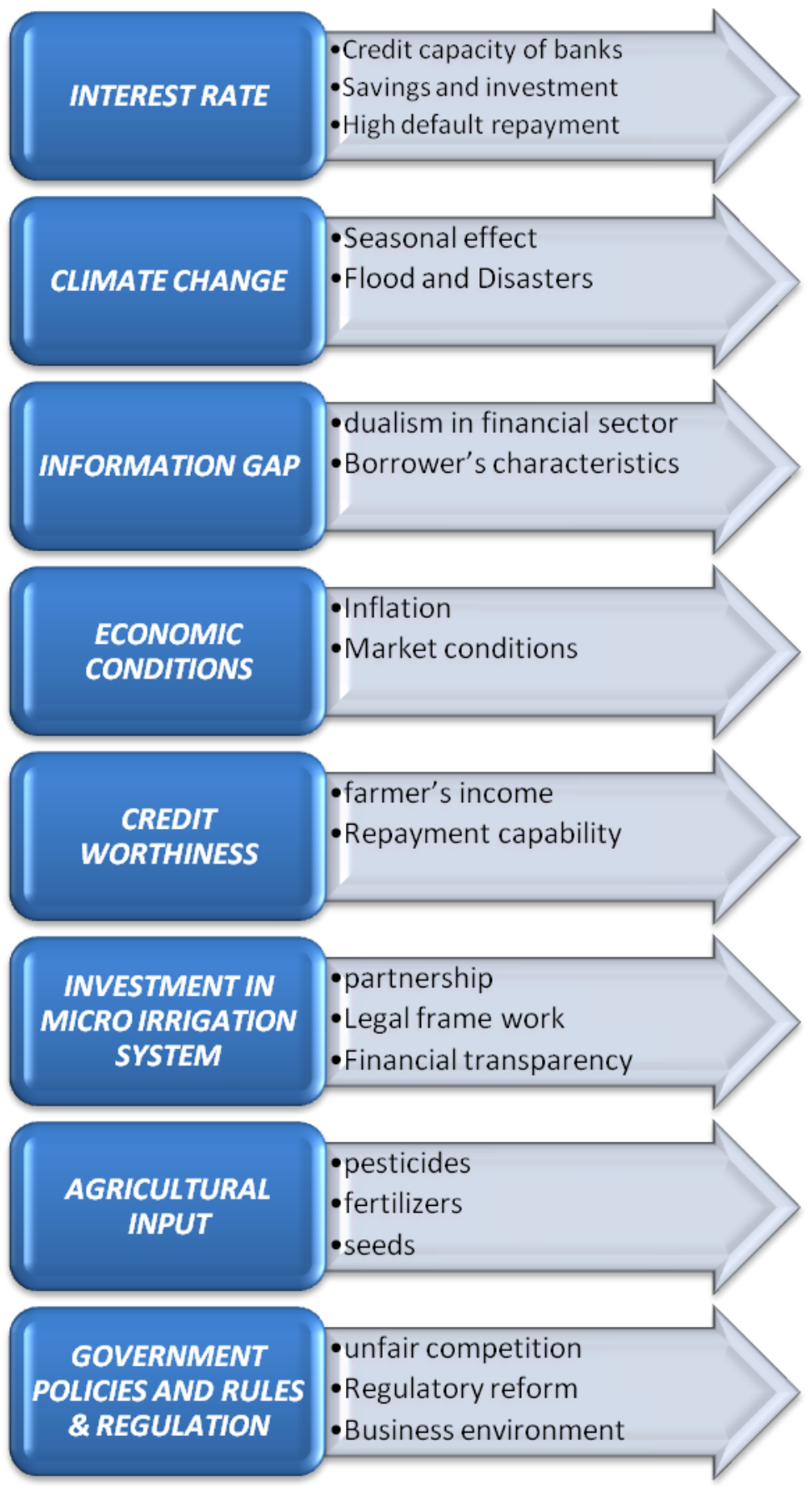

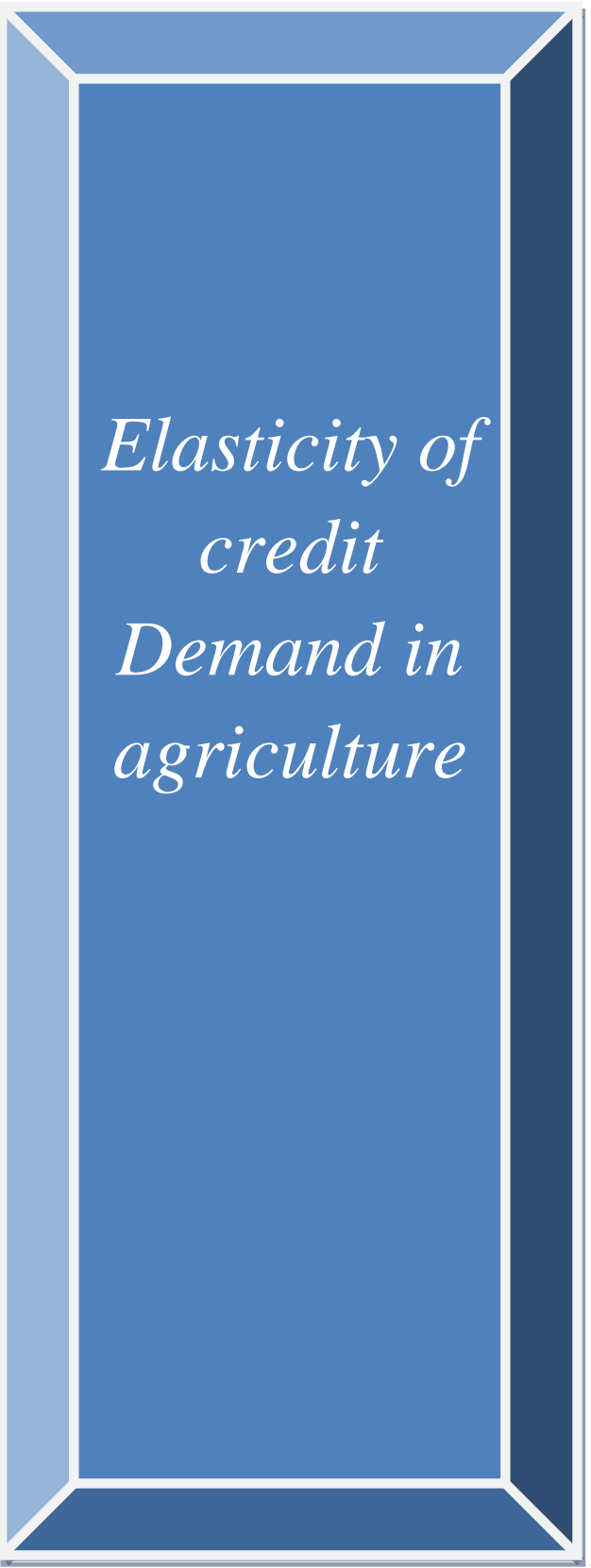

www.macrothink.org/ijld 


\section{Ml Macrothink}

4. Hypotheses:

2012, Vol. 2, No. 1

In an effort to attain the research goals, eight hypotheses are developed. These remain free of research so far.

\section{Climate Change:}

$\mathrm{H} 0$ : There is no significant positive relationship between climate change and demand elasticity of rural credit.

H1: There is significant positive relationship between climate change and demand elasticity of rural credit.

\section{Interest rate:}

H0: There is no significant negative relationship between interest rate and demand elasticity of rural credit.

H1: There is significant negative relationship between interest rate and demand elasticity of rural credit.

\section{Information Gap:}

H0: There is no significant negative relationship between information gap and demand elasticity of rural credit.

H1: There is significant negative relationship between information gap and demand elasticity of rural credit.

\section{Economic conditions:}

$\mathrm{HO}$ : There is no significant positive relationship between economic conditions and demand elasticity of rural credit.

H1: There is significant positive relationship between economic conditions and demand elasticity of rural credit.

Investment in micro irrigation system:

$\mathrm{HO}$ : There is no significant positive relationship between investment in micro irrigation system and demand elasticity of rural credit.

H1: There is significant positive relationship between investment in micro irrigation system and demand elasticity of rural credit.

Government Policies Rules \& regulation:

H0: There is no significant positive relationship between Government policies rules \& regulation and demand elasticity of rural credit.

H1: There is significant positive relationship between Government policies rules \& regulation and demand elasticity of rural credit.

Agricultural Input:

H0: There is no significant positive relationship between agricultural input and demand elasticity of rural credit.

H1: There is significant positive relationship between agricultural input and demand elasticity of rural credit.

\section{Credit Worthiness:}

H0: There is no significant positive relationship between credit worthiness and demand elasticity of rural credit.

H1: There is significant positive relationship between credit worthiness and demand elasticity of rural credit. 


\section{Research methodology:}

The actual sample size in the study is 100 respondents. The returned questionnaires were included for the statistical investigation. The sample consisted of farmers from south Punjab. What might be considered as a restriction is that the research was conducted in only one region, and could not, therefore, be generalized to the whole country. The sample size and the number of the respondents were assumed to be sufficient in providing comprehensive results. For the purpose of this study, the chi square test was adapted. Descriptive analyses a total of 100 respondents participated in the survey. Most of the respondents were male.

\section{Empirical analysis and results:}

\begin{tabular}{|lll|}
\hline Variables & Mean & $\begin{array}{l}\text { Std. } \\
\text { Deviation }\end{array}$ \\
\hline Climate change & 1.72 & 0.73 \\
\hline Interest rate & 2.19 & 0.90 \\
\hline Information Gap & 2.19 & 1.06 \\
\hline Economic Condition & 3.00 & 1.15 \\
\hline $\begin{array}{l}\text { Investment In Micro Irrigation } \\
\text { System }\end{array}$ & 2.18 & 0.97 \\
\hline $\begin{array}{l}\text { Government Policies Rules \& } \\
\text { regulation }\end{array}$ & 2.73 & 1.04 \\
\hline $\begin{array}{l}\text { Agriculture inputs } \\
\text { Credit worthiness }\end{array}$ & 2.14 & 1.11 \\
\hline
\end{tabular}

\section{Discussion Findings:}

When statistical tools are applied we concluded that climate change, interest rate, investment in micro irrigation system, and credit worthiness are the variables which have least variation in the results that shows these variables are highly effective on the demand of credit in Agriculture sector. As for as concerned other variables as like informational gap, economic conditions, government policies rules and regulation, and agriculture inputs have also impact on demand of credit but least impact as compared to other factors because these have more variation in statistical findings. Consequently, we can say the variables which have least variation have strongly relationship and those variables which have more variation have ineffective relationship with demand of credit.

The results indicate that most of the people are strongly agree with the increase and decrease in the interest rate will affect the credit demand negatively. The relationship between the interest rate and credit demand is inversely proportional. The mean of interest rate is 2.19 and the deviation from the standard value is 0.90 . This means that mostly people agree at this statement when interest is increased the credit demand decreased and vice versa. The chi scale test exhibits that there is a significant effect of interest rate on demand of credit. So we will accept our $\mathrm{H} 1$ because interest rate in negatively respond to credit demand because by increasing credit demand, credit capacity of bank will reduce. So 
it will grant fewer loans to farmers. People will not take loan on high rate because it will increase default in repayment.

When the primary data was gathered from the target respondent regarding effect of climate change, they provided feedback that the climate changes affect the credit demand very strongly. The climate changes are strongly associated with credit demand. The mean of climate changes is 1.725 and deviation from the standard value is very low. The value of mean that is 1.725 describe that mostly people are agree with this statement. So we can conclude that mostly farmers have less variation in perception about climate change. Agriculture has highly positive effect on the credit demand because farmer will increase demand when there is any extreme climate condition and other disasters. We will accept our $\mathrm{H} 1$ because Chi square test verify that there is significant positive effect of change in season and flood and disaster effect on requirement of credit.

Statistical results have given the mean of 2.19 and standard deviation of 1.06. It shows that there is less variation from mean value. Chi square results also have shown that overall result was strongly agreed. Information Gap has a huge impact on credit demand in rural sector. If there is an information Gap between lender and borrowers, then there will be less demand of rural credit. As mostly in rural areas people are illiterate or less educated. They hesitate to go to financial institutions because loan borrowing procedures are not understandable. On the other hand financial institutions don't have trained employees who may provide better information to the rural population. Most of the peasants agree that information gap has a significant impact on credit demand.

Result showed from statistical tools gave the mean of 3.00 and standard deviation of 1.5. It shows the high variation from mean. From the statistical result we find that credit demand is not much affected by the economic condition. The Chi square results also show that Economic conditions affect the demand of credit but not significantly. The economic condition has least impact on the demand for credit because the result shows more variation as compared to the other factors that have less variation in the result. Economic conditions like inflation, deflation, market conditions etc are not directly affecting the credit demand in rural sector. To some extent, repayment of loan becomes difficult for debtors but not necessarily because if inflation and interest increases then on the other hand market value of crops is also increased. Hence employees have to invest more; they also get more in return of investment. In short peasants were indifferent in their opinion regarding factor of economic conditions.

Respondents gave their positive feedback in relation to the micro investment. Most of them agreed strongly that this type of investment is highly affected the credit demand. People like to borrow the credit for this type of investment. People invest this money in those areas where they think that by this investment they can enhance their productivity. The mean of the investment in micro irrigation system is 2.18 and the deviation from the standard value is 0.97 that shows that it has less deviation in the opinions of people. Consequently, we can say that the investment in micro irrigation system and credit demand is highly associated with each other.

After finding the result we concluded that mostly people are indifferent to give their suggestions about this but some of them are agree that proper standardized rules and regulations should be implemented in financial sector for credit enhancement. The policy 
rules and regulation made by the government must be in the favor of borrower as well as lender. The mean value is 2.73 and deviation from the standard value is 1.04 . Now we conclude that the relationship between government policies and rules \& regulation and credit demand elasticity is strong but weak as compared to the other variables.

Chi scale test shows the highly significant affect of agricultural input on demand of credit. From the statically tool we find that the standard deviation about the agricultural input is 1.11 and the mean of it is 2.14 . There is a less deviation from mean which show that mostly the farmer agree that the demand of loan affected by the agricultural input in other way its mean there is a significant effect of agricultural input (high quality seeds, fertilizers, and water system etc) on the demand of credit by the farmer Positive relationship with credit demand in rural sector. The chi-square result shows that Agricultural input has significant positive relationship with credit demand in rural sector Mostly the farmer agrees on the demand of credit is now increasing for the purchase of agricultural input. The purpose is to increase the production capacity and for the production of high quality crop. In order to fulfill the current requirement of food mostly the framer needs the capital for investing more in order to increase the production and make it more profitable for them as they demand the credit for the agricultural input.

Whereas the result shows about the credit worthiness in table, there S. $\mathrm{d}$ is 0.89 and the mean is 1.71 hence a least variation is found. It indicates the people strongly agree that the creditworthiness is one of the most significant factors which affect the credit lending and its demand. The chi-square result shows that credit worthiness of borrower has significant positive relationship with credit demand in rural sector of Pakistan. The character, capacity to repay the credit, capital, collateral and the conditions are the five C's which is mostly take in consideration by the lender while lending the loan. If the past character of farmer about the repayment of credit is not good the lender will not provide him the loan. They also have a concern on his personal wealth such that they make the estimation either they have an ability to pay their loan after any mishap. So the poor farmer has no so much capital and doesn't have anything more to pledge their assets for getting loan so they not demand the loan. So the credit demand in agricultural sector is affected by the factor of credit worthiness.

When statistical tools like mean, median, standard deviation are applied on the data collected from the target respondent, the results show that the variable of micro irrigation system has a strong relationship with the micro credit elasticity. Because the deviation in the results is very low 0.97 , it's mean it is strongly associated with credit elasticity. The results that are concluded after applying statistical analysis we found that standard deviation between the opinions of target respondent is very high 1.04 as compared to other variables. So we found the relationship between government policies and elasticity of credit demand is low as compared to other variables. The relationship is present but not highly associated.

\section{Conclusion /Further Research Recommendations}

The research paper has identified the eight major factors which cause elasticity in rural credit demand. The paper has explained the effect of these various factors from the prospective of peasant. An instrument for identifying the outcome of factors has been 
possibly developed for the first time in Pakistan. It also revealed the relationship among Government, peasant and financial institute from peasant prospective. The major findings of this survey are concluded as follows; Government rules and regulations have less effect than other factors. Whereas interest rate offered by financial institute, economic conditions of country, investment in micro irrigation system and use of agriculture input have large effect on credit elasticity of demand in rural areas. Furthermore, dualisms in financial sector and credit worthiness of borrower have highly significant effect on credit demand.

There is a negative relationship between the interest rate and the credit demand. The government of Pakistan should make favorable policies about interest rate so that farmers can make easy repayment of loan. The result also shows that extreme climate changes and other natural disasters like flood, earthquake, etc. cause high demand for the credit in rural areas. It is recommended that financial institutions like banks should develop special rules and policies. In case of disaster or any extreme changes in climate conditions in the specific areas, such rules and policies must be lenient for the effected people. Information gap between lender and borrower is another major reason of less credit demand. The main reason behind these phenomena is illiteracy or less qualification of rural population. It is recommended that bank should conduct such seminars to create awareness about credit borrowing. It is extracted that economic conditions have limited impact on credit demand. In micro irrigation system micro investment increases and due to increase in this investment the demand for credit in the rural population also increases. To improve their agriculture production farmers need to improve their agriculture inputs like as high yielding verity of seeds, adequate irrigation system and fertilizers etc. so farmer demand for credit to fulfill these demands.

Financial institutions require that borrower should pledge his assets to borrow loan. This factor also reduces the credit demand in rural areas. Financial institutions and government should organize special credit programs and should develop specific rules and regulations if borrower has less credit worthiness and don't have capability to pledge their assets. Furthermore farmers should be provided such opportunities to make more investment in micro irrigation system.

\section{References}

Agbelie, C., 2001, "Poor Loan Recovery at Ho Assembly", Daily Graphic Newspaper, Accra, Ghana, September 14, p.13.

Ahmed, M. N., \& Schmitz, M. (2011). Economic Assessment of the impact of climate change on the agriculture of pakistan. Germeny: Justus-Liebig-University of Giessen. Anderson, J, 1990. "Does Regulation Improve Small Farmers" Access to Brazilian Rural Credit” Journal of Development Economics, 33, pp 67-87

Anderson, J. R. \& Hamal K. B. 1983, 'Risk and rice technology in Nepal', Indian Journal of Agricultural Economics, vol. 38(2), pp. 217-222.

Ani, 1988. Cited in Akiri and Adofu, 2007. Interest Rate

Deregulation and investment in Nigeria. J. Econ.Manag. Stud., 2(1). 


\section{$\triangle$ Macrothink}

Anwar M.M, 1993: geography of Pakistan. Book-World Islamabad and Lahore, pp. 20-60. Ashley Hubka, the School of Advanced International Studies (SAIS), John Hopkins University, and Rida Zaidi is a PhD candidate in Economics at Cambridge University, UK WORLD DEVELOPMENT REPORT IN 2005.

Besely, T., and S. Coate, 1995, "Group Lending, Repayment Incentive and Social Collateral”, Journal of Development Economics, Vol. 46, No, 1, p. 1-18

Bosher, L., Dainty, A., Carrillo, P., Glass, J., \& Price, A. (2009). Attaining improved resilience to floods: a proactive multi-stakeholder approach. Disaster Prevention and Management, Vol. 18 No. 1. pp.9-22.

Boyd, John, Ross Levine and Bruce Smith (2001), "The Impact of Inflation on Financial

Sector Performance", Journal of Monetary Economics, 47, pp. 221-248.

Cabinet Office/HM Treasury (2006), Stern Review on the Economics of Climate Change, Cabinet Office/Her Majesty's Treasury, London.

De Meza, D., Webb, D.C., 1992, "Efficient credit rationing: European Economic Review". Duca, John V. and William C. Whitesell (1995), "Credit Cards and Money Demand: A Cross-sectional Study", Journal of Money, Credit and Banking, Vol. 27, No. 2, pp. 604-623.

Ekumah E.k. \& Essel T. T. (2003). Information is power. The problem with credit accessibility in rural banks in Ghana. Ghana: International labor organization 2002.

Fernando, N. (2003), The Changing Face of Microfinance: Transformation of NGOs into Regulated Financial Institutions, Asian Development bank.

Fry, M.J., 1995. Money Interest and Banking Economic Development. 2nd Edn., Johns, Hopkins University Press, Baltimore MD.

Greenwood and Jovanorie, 1990. Ibimodo, 2005; Abiodun, 1988. (Cited in Akin E.S. and I. Adofu, 2007) Interest rate deregulation and investment in Nigeria. J. Econ. Manag. Stud., 2(1).

Gustafson. C.R. "Credit Evaluation Monitoring the Financial Health of Agriculture." Amer.J.Agr.Econ. 71(1989):1145-1151

Hardwick J., B. Khan and J. Langmead. (1990). Introduction to Modern Manag. Stud., 2(1).ics Review, Vol. 71, No. 3

Helms, B. (2006). Access for All. Building Inclusive Financial Systems. Washington: Consultative Group to Assist the Poor (CGAP) /The World Bank.

Henderson, J. (2009). Agricultural Credit Standards Tighten. Federal Reserve Bank of Kansas City.

Hoff K., Braverman A. \& Stiglitz J. E. (eds.), (1993). The economics of rural organization: Theory, practice and policy. Oxford University Press for the World Bank, EE.UU.

HUDON, M. (2007), Ethics and Economics, 5 (1), Retrieved March 19, 2011 from http://ethique-economique.net/Volume-5-Numero-1.html.

IPCC (2007) Intergovernmental Panel on Climate Change, 4th Assessment Report. Climate Change

Iqbal, M., Ahmad, M., \& Abbas, K. (2003). The Impact of Institutional Credit on Agricultural. The Pakistan Development Review , 469-485. 


\section{Macrothink

Janjua, D. P., Samad, G., \& Khan, N. U. (2009). Impact of Climate change on wheat Production . Flood Mnagement in a Changing Climate .

Lai K. C. and Cistulli V. (2005). Decentralization of Agricultural Service.

Mackinnon, R., 1973. Money and Capital in International Development. The Broken ness Institution Washington DC.

Meagher, P., 2002, Microfinance Regulation in Developing Countries: A Comparative Review of Current Practice, IRIS Center, University of Maryland.

Mei Dong (October 13, 2008) "Inflation, Money Demand and Credit".

Mohamed, K. (2003). Research on Poverty Alleviation. Tanzania: Mkuki na Nyota Publishers.

Morduch, J. (2000). The Microfinance Schism. World Development, 28(4), 617-629.

Mpuga, P. (2004). Demand for credit in Rural Uganda: Who cares for the peasants? A Paper Presented at the Conference on Growth, Poverty Reduction and Human Development in Africa Centre for the Study of African Economies March 21-22.

Nagarajan, G. \& Meyer, R.L. (2005). $\quad$ Rural Finance: Recent Advances and Emerging Lessons, Debates, and Opportunities. Working Paper: AEDE-WP-0041-05. Ohio: The Ohio State University, Department of Agricultural, Environmental, and Development Economics.

Nwankwo, G.O., 1989. Nigerian Financial System. Macmillan Publishers Ltd.

Qureshi, Sarfraz Khan, and Akhtiar H. Shah (1992) A Critical Review of Rural

Credit Policy in Pakistan. The Pakistan Development Review 31:4, 781-801.

Shaw, E.S., 1973. Financial Deepening in Economic Development. Oxford University Press Oxford.

Sjah, Cameron \& Russell 1school Of Nrsm, University of Queensland, Gatton Campus, Australia, 2Faculty of Agriculture, University of Mataram, Indonesia

Stiglitz, J., 1993. "Incentives, organizational structures and contractual choice in the reform of socialist Agriculture".

Stiglitz, J.E. and A. Weiss, 1981, 'Credit Rationing in Markets with Imperfect Information”, American Economics Review, Vol. 71, No. 3

Swinnen, J.F.M., 1994. In: Schmitz, A., Moulton, K., Buckwell, A., Davidova, "Privatization of Agriculture in New Market Economies".

Van Greuning, H., Gallardo, J., and Bikki Randhawa, 1998, A Framework for Regulating Microfinance Institutions, Financial Sector Development Department, The World Bank December.

World Bank, February,2003, Strategy for the Financial Sector, Financial Sector Board World Food Institute, 1988. World food trade and U.S. agriculture, 1960-1987, AmesIowa State University

YARON, J. June 2003, State-Owned Development Finance Institutions (SDFI): Assessing Their Performance, World Bank.

Zeller, M. (2003). Models of Rural Financial Institutions. Lead Theme Paper at Paving the Way Forward for Rural Finance: An International Conference on Best Practices, Washington, D.C., June 2-4, 2003.

Zuberi, Habib A. (1989) Production Function, Institutional Credit and Agricultural Development in Pakistan. The Pakistan Development Review 28:1, 43-56. 